\title{
Deceptive Strategies in Literature: The Meaning of Folded Story
}

\author{
Silvia Rosa \\ Faculty of Cultural Sciences, Universitas Andalas, Indonesia \\ Email: sylvierosha2@gmail.com
}

\begin{abstract}
Tambo Minangkabau is a storehouse of knowledge about the history of the Minangkabau people. Initially, it developed as oral literature, passed from generation to generation in the Minangkabau community in West Sumatra, an Indonesian provinces with a matrilineal kinship structure. However, after the Minangkabau people embraced Islam, Tambo began to be written using Jawi characters in Arabic thus becoming an historical literary work. Tambo tells the history of the Minangkabau ethnic group and also the history of customs and Minangkabau culture. Tambo records past events, stories about the origins of Minangkabau ancestors, philosophy, norms and laws in community life, and even the tragedies that have occurred in this ethnic group. To express the tragedies that have occurred in the past history of the Minangkabau ethnic group, Tambo uses the power of symbolic language. There are two episodes in Tambo that illustrate this. This article reveals the strategy of hiding a tragedy by the Minangkabau tribe through the power of the use of language in historical literary works, especially those depicted in the episodes of "Teka-teki Kayu Tataran" and "Teka-teki Unggas".
\end{abstract}

Keywords: historical literature; Minangkabau; Tambo; puzzles; "Teka-teki Kayu Tataran”; "Teka-teki Unggas"

\section{INTRODUCTION}

Tambo Minangkabau consists of four episodes in the main section, and five episodes in the additional section. This article discusses two episodes including the main part. The selection of the two episodes is based on the consideration that they are an important part of Tambo, that is the narratives about the past tragedies in the history of the Minangkabau civilization. The tragedy is embedded or folded into the literature, especially in puzzles. Djamaris (2001) states that puzzles are one genre of oral literature (See also ; Batiran (2011); Andriani (2012)). As a language unit, puzzle activities reflect the speaker's pride toward a language. (Wijana, 2013). The episode "Teka-teki Kayu Tataran" ("The Puzzle of the Notched Wood") in the Minangkabau Tambo tells the story of playing puzzles between two groups. The first group came by boat from across the sea to the ancestral lands of the Minangkabau people. They landed in the country of the Limo people. They brought a type of wooden artifact called kayu tataran. The second group is the Minangkabau people who live in a region called Lima Kaum Dua Belas Koto. They are natives of the Minangkabau ethnic group. The group arriving by boat invites the visited group to play puzzles using the wood they carried in the boat. The game was won by the visited group.

The next episode, "Teka-teki Unggas" ("The Puzzle of the Fowl") tells the story of the return of a Great Captain to Perca Island, another name for Sumatra. The Great Captain's entourage landed in a country onPerca Island. The region is called Tanjung Sungayang. He arrives on a large boat carrying two fowl, a male and a female. The Great Captain then meets the leader on Perca named Cati Reno Sudah. He invites Cati Reno Sudah to play puzzles using the pair of birds he carried on the ship. 
Cati Reno Sudah accepted the puzzle game invitation. All the people of Tanjung Sungayang gathered to watch the puzzle game. The puzzle game was won by Cati Reno Sudah, one of the leaders in the Minangkabau village.

An important reason for discussing the two episodes contained in the Minangkabau Tambo, is due to the symbolic power behind the puzzle game narrative. There is an "embedded" or "folded" story in the second episode of Tambo. Tambo is an historical literary work belonging to the Minangkabau ethnic group. Historical literary works are also referred to as one of the traditional historiographic varieties (Firmanto, (2015); Lutzeler (2015)); which function not only to record history, but also provides interesting and pleasant entertainment as a reading (Fee and Stuart in Siahaan, (2015); Putra (2011)). Historiography contains information about an ethnic group, state, and also culture (Krebs, 2018); through historiography "immersed history" called subaltern can be reconstructed (Spivak, 2012). Tambo as traditional historiography contains important information about the past of the Minangkabau people, although the facts of the past are clad in connotative diction. The connotation that is stored behind the local language, which is used as an introduction to the ideas, ideas and collective feelings of the Minangkabau tribe needs to be interpreted carefully. This is because the language used in Tambo is language at a deeper level. Therefore, semiotic theory is relevant to use as a frameworkin interpreting the two episodes of Minangkabau Tambo mentioned..

Semiotics is the science of the signs and meanings contained behind the sign. Semiotics provides a crossdisciplinary perspective (Jensen, 2015); even broader themes can be developed which can be traced to semiotics (Eco, 2018); Dick (2010); Zlatev (2015); Wong (2018). Barthes's semiotic approach is appropriate to use to interpret the narrative of Minangkabau Tambo, especially for the episode "Teka-teki Kayu Tataran" and the episode "Teka-teki Unggas". The concept of the five codes appliedby Barthes in analysing Sarrasine by Balzac, provides opportunities for a more detailed text analysis. A unit of text is called a lexia, which is then analysed and categorised using five codes: hermeneutic; semic; symbolic; proairetic; and cultural (Barthes, 1974). The data in this paper was obtained from the Minangkabau Tambo text. The unit of analysis, in the form of textual fragments, is called lexia. The collectedlexia is used to concretize the meaning of the narrative in "Teka-teki Kayu Tataran" and "Teka-teki Unggas". The study of the meaning in literature by analyzing lexia can allow adeeper interpretation of a text. Isaac (2005) has also applied the five Barthes semiotic codes to the study of architecture; and also to cultural heritage buildings (Habsari 2015).

A qualitative method is used in this research, that is, a textual analysis of Tambo Minangkabau. The object of this research material is the transcription of Tambo Minangabau (Djamaris, 2001). Data is collected and grouped as units of lexia in the two selected Tambo Minangkabau episodes. Data analysis was carried out by determining the semiological aspects of the lexia, the "folded story" in Tambo Minangkabau, especially those contained in the episodes of "Teka-teki Kayu Tataran" and "Teka-teki Unggas" as acts of meaning. The classification of this data uses the five codes developed by Roland Barthes. Pramudia (2012) has applied it to Gie's analysis, Film Scenario Manuscript; Nuswantara (2014) for journalistic photos; and Girsang (2016) on television advertisements, also Lustyantie (2012) on French literature; and Widyatwati (2015) on an Indonesian short story entitled "City Bus". Similar analyses of traditional Javanese texts have also been carried out by Koswara (undated), but has never been applied to historiographic research on traditional Minangkabau texts, especially those related to Tambo Minangkabau.

\section{DISCUSSION \\ Results and Discussion}

The two episodes of Tambo Minangkabau that have been analysed can be broken down into several units of analyses, which then become the basis for interpreting the meaning at a deeper level in the second part of the Tambo episode. The unit of analysis is explained in the following section.

\section{Results}

This episode of "Teka-teki Kayu Tataran" tells the story of the coming of a boat from the sea to the land of Lima Kaum Dua Belas Koto, which carries a notched wooden puzzle. The boat's captain invites Datuk Suri Dirajo to play the puzzle. The text was found to contain 62 units of analyses (See also a similar research method used by Junus (1988)). The results of the analysis are detailed in Table 1.

Furthermore, the episode "Teka-teki Unggas" tells of the events of the return of a Great Captain to Perca Island, accompanied by a group. He brought a pair of birds to be used as a puzzle game with the people of Perca Island. The offer to play the puzzle was accepted by its leaders. Cati Reno Sudah was already a traditional leader in Perca, especially in the land of Tanjung Sungayang (Cape Sungayang), inviting all residents of the country to watch the puzzle game. 
Table 1. Episode “Teka-teki Kayu Tataran" Units of Analysis

\begin{tabular}{|c|c|c|}
\hline No & Original Text & Translation \\
\hline 1 & Maka berapalah lama antaranya, & After some time had passed, \\
\hline 2 & maka datang pula perahu orang dari pada laut & there came a foreign boat from the sea \\
\hline 3 & kepada negeri Lima Kaum Dua Belas Koto, & to the land of the Five Clans and Twelve Towns \\
\hline 4 & (manapek) & landed \\
\hline 5 & membawa kayu tataran nago pipik. & Carrying the sparrow dragon-notched wood \\
\hline 6 & Maka berkata nakhodanya kepada Datuk Suri Dirajo, & Then the skipper said to Datuk Suri Dirajo \\
\hline 7 & "Marilah kita bartakok-takok." & "Let’s play puzzles" \\
\hline 8 & Maka sekalian isi negeri keluar belaka. & Thus all the people came out out \\
\hline 9 & Maka bertaruh lima puluh kati emas banyaknya. & Then a fifty catty $*$ bet in gold was made \\
\hline 10 & $\begin{array}{l}\text { Maka dilawan oleh isi negeri semuhanya laras nan } \\
\text { dua, }\end{array}$ & So he was opposed by all the people of two areas \\
\hline 11 & yaitu Laras Bodi Caniago dan Laras Koto Piliang. & namely, Laras Bodi Caniago and Laras Koto Piliang \\
\hline 12 & Taruh berlawan oleh isi negeri. & Bets were wagered \\
\hline 13 & $\begin{array}{l}\text { Maka isi perahu keluar belaka semuahnya ke tengah } \\
\text { medan yang baik, }\end{array}$ & $\begin{array}{l}\text { Everyone on the boat alighted and went to the middle } \\
\text { of a good field }\end{array}$ \\
\hline 14 & yaitu (kepada) Dusun Tua. & namely, in Tuo Village \\
\hline 15 & Maka berkata Cati Reno Sudah, & Then Cati Reno Sudah said, \\
\hline 16 & $\begin{array}{l}\text { "Apa maksud Tuan Nakhoda Besar kepada negeri } \\
\text { kami?" }\end{array}$ & $\begin{array}{l}\text { "For what purpose does the Great Captain come to our } \\
\text { country?" }\end{array}$ \\
\hline 17 & $\begin{array}{l}\text { Maka sahut Nakhoda Besar, "Akan menjalani Pulau } \\
\text { Perca, }\end{array}$ & The captain replied "To journey through Perca Island" \\
\hline 18 & $\begin{array}{l}\text { adalah orang cerdik lagi laut bicara dan budi akal di } \\
\text { negeri Pulau Perca. }\end{array}$ & $\begin{array}{l}\text { The people are clever speak as one and are of good } \\
\text { sense on Perca Island. }\end{array}$ \\
\hline 19 & Itulah nan aku jelang." & That is what I seek " \\
\hline 20 & Maka berkata Nakhoda Besar di lautan, & Then the Great Captain said \\
\hline 21 & $\begin{array}{l}\text { "Takok olehmu hai isi negeri Pulau Perca ini akan kayu } \\
\text { tataran nago pipik, }\end{array}$ & $\begin{array}{l}\text { "Make a guess all of you of Perca Island about the } \\
\text { sparrow dragon notched wood,. }\end{array}$ \\
\hline 22 & maka mana pangkalnya dan mana ujungnya ?" & Which part is the base and which is the end? ' \\
\hline 23 & $\begin{array}{l}\text { Maka berkata sekalian isi alam kepada Datuk Suri } \\
\text { Dirajo. }\end{array}$ & Then speaking to all Datuk Suri Dirajo said \\
\hline 24 & $\begin{array}{l}\text { "(Hai segala isi alam,) kati olehmu kayu itu di } \\
\text { tengahnya, }\end{array}$ & $\begin{array}{l}\text { "(O all of this world, }), \text { weigh you the wood in the } \\
\text { middle" }\end{array}$ \\
\hline 25 & mana yang berat, itulah pangkalnya." & that part which is heavy, then that's the bottom part ". \\
\hline 26 & Maka tiba di tengah medan & Arriving in the middle of the field \\
\hline 27 & maka berkata Cati Reno Sudah, apalah katanya, & said Cati Reno Sudah \\
\hline 28 & "Hai Tuan Nakhoda Besar, & "Hey Great Captain, \\
\hline 29 & jika tatakok oleh kami, & If guessed by us \\
\hline 30 & apakah akan hukumnya?" & Is there a law? " \\
\hline 31 & Maka sahut Nakhoda Besar, & The Great Captain responded \\
\hline 32 & $\begin{array}{l}\text { "Sekalian taruh itu milikilah oleh engkau, hai isi } \\
\text { alam," }\end{array}$ & "Take all the bets if you win" \\
\hline
\end{tabular}




\begin{tabular}{|c|c|c|}
\hline 33 & Maka menyahut Cati Reno Sudah, "Baiklah kata itu." & Then Cati Reno Sudah answered “Okay then” \\
\hline 34 & Maka ditariknya kayu tataran nago pipik, & Then he pulled the sparrow dragon notched wood \\
\hline 35 & maka diikati oleh Cati Reno Sudah akan panjangnya, & Then tied by Cati Reno Sudah lengthwise. \\
\hline 36 & maka dilipatnya, diukurnya, & Then folded and measured. \\
\hline 37 & maka dijareknya pada tengah-tengah lipatnya itu. & Then tied in the very the centre of the fold \\
\hline 38 & maka dikatinya kayu itu, & Then he weighed it \\
\hline 39 & akan seperdua, & As halves, \\
\hline 40 & maka berat yang sebelah kanan, & thus the weight was on the right \\
\hline 41 & maka ditakok oleh Cati Reno Sudah, & So it was guessed by Cati Reno Sudah \\
\hline 42 & nan berat itulah & That thatwas the heavy part \\
\hline 43 & Maka alahlah Nakhoda Besar itu. & Thus the Great Captain lost \\
\hline 44 & Maka larilah inyo lai, & So they ran away from that place \\
\hline 45 & lagi malu. & Embarrassed, \\
\hline 46 & $\begin{array}{l}\text { Maka segala perahu tadi tinggal semuhanya di Sungai } \\
\text { Emas. }\end{array}$ & All these boats stayed on the Golden River \\
\hline 47 & Itulah yang jadi kapal Padang Ganting. & That is what happened to the Padang Ganting ship. \\
\hline 48 & Maka sekalian arato itu dibelah oleh laras nan dua, & $\begin{array}{l}\text { Then the whole property was divided by the two } \\
\text { towns. . }\end{array}$ \\
\hline 49 & sebelah ke Pariangan Padang Panjang & a half to Padang Panjang Pariangan \\
\hline 50 & dan sebelah dibahagi (tiga) & and the other half wasdivided into three parts \\
\hline 51 & $\begin{array}{l}\text { sebahagi ditinggalkan pada Lima Kaum Dua Belas } \\
\text { Koto, }\end{array}$ & $\begin{array}{l}\text { A share was left to the Five Clans of } 12 \text { Towns (Limo } \\
\text { Kaum Dua Belas Koto) }\end{array}$ \\
\hline 52 & nan sebahagi lagi ke Sungai Tarab & and another part goes to the Tarab River \\
\hline 53 & dan lalu ke Tanjung Sungayang. & and up to Sungayang Cape. \\
\hline 54 & Maka bersumpah-sumpah di sana segala orang itu, & Then, all the groups there made oaths \\
\hline 55 & $\begin{array}{l}\text { "Sekali-kali jangan kita ke Minangkabau dan ke Pulau } \\
\text { Perca ini }\end{array}$ & $\begin{array}{l}\text { "Never again will we come to Minangkabau and to } \\
\text { Perca Island }\end{array}$ \\
\hline 56 & karena orang Pulau Perca dalam bicara daripada kita." & $\begin{array}{l}\text { because of the people of Perca Island in speaking of } \\
\text { us." }\end{array}$ \\
\hline 57 & Sebab itulah tiada datang lai ke Pulau Perca. & Because of that they no long came Perca Island. \\
\hline 58 & $\begin{array}{l}\text { Maka berapalah lamanya Datuk Katumanggungan pun } \\
\text { berpindah ke Koto (Ranah) }\end{array}$ & $\begin{array}{l}\text { After some time, Datuk Katumanggungan then moved } \\
\text { to Koto Ranah }\end{array}$ \\
\hline 59 & $\begin{array}{l}\text { dan Datuk Parpatih nan Sabatang pun berpindah ke } \\
\text { Solok Salayo. }\end{array}$ & $\begin{array}{l}\text { and Datuk Perpatih and Sebatang moved to Solok } \\
\text { Selayo }\end{array}$ \\
\hline 60 & Maka sekalian isi negeri semuhanya & Then all the inhabitants \\
\hline 61 & luak nan tigo & of the districts Luhak Nan Tiga \\
\hline 62 & sudah bacupak bagantang & Have rules and standards \\
\hline
\end{tabular}

Note: * Catty (kati) is a unit of measure for weight. One catty is 625 grams, 50 catty is $31.25 \mathrm{~kg}$ 
Table 2. "Teka-teki Unggas" Episode Units of Analysis

\begin{tabular}{|c|c|c|}
\hline No & Original Text & Translation \\
\hline 1 & Maka lama pulalah antaranya, & So after a while, \\
\hline 2 & maka datang pula Nakhoda Besar ke Pulau Perca ini & came the Great Captain to this island \\
\hline 3 & akan membawa unggas dua ekor, & carrying two fowl \\
\hline 4 & seekor jantan seekor betina, & one male, one female \\
\hline 5 & sama keduanya, & both the same, \\
\hline 6 & rupanya dan gadangnya, & in appearance and size, \\
\hline 7 & paruhnya dan bunyinya. & their beaks and sounds \\
\hline 8 & Maka mandapek ke Tanjung Sungayang, & They headed to Tanjung Sungayang \\
\hline 9 & ialah pangkal bumi namanya. & the origin of the earth is its name \\
\hline 10 & Maka tiba di sana mufakatlah segala isi alam. & So on arrival there all were in agreement. \\
\hline 11 & $\begin{array}{l}\text { Maka berkata Nakhoda Besar kepada Cati Reno } \\
\text { Sudah, }\end{array}$ & The Great Captain said to Cati Bilang Pandai \\
\hline 12 & "Marilah kita bartakok tiada bertaruh. & Let's play a game without betting, \\
\hline 13 & "Maka kata Cati Reno Sudah, "Baiklah.” & Cati Reno Sudah said, “Agreed”., \\
\hline 14 & Maka berkampunglah ke tengah medan, & $\begin{array}{l}\text { Then the whole population gathered in the middle of } \\
\text { the field,. }\end{array}$ \\
\hline 15 & maka segala isi alam rapat-rapat semuhanya melihat. & All crowded together watching the match. \\
\hline 16 & Maka diminta bicara kepada Datuk Suri Dirajo. & Then asked to speak to Datuk Suri Dirajo. \\
\hline 17 & Adapun pitua Datuk Suri Dirajo, & Concerning Datuk Suri Dirajo’s advice, \\
\hline 18 & "Apa kata Nakhoda Besar, & What does the Great Captain say, \\
\hline 19 & mana yang jantan, & Asking which one is male. \\
\hline 20 & mana yang betina?" & Which one is female? \\
\hline 21 & Maka pikirlah segala isi alam. & Then think hard of all of this world. \\
\hline 22 & $\begin{array}{l}\text { Maka diberi kata oleh Datuk Suri Dirajo segala isi } \\
\text { alam ini }\end{array}$ & Then Datuk Suri Dirajo gave advice to all of this world \\
\hline 23 & "Beri makan olehmu keduanya, & "Give them food, \\
\hline 24 & mana yang kuat makannya & The which one eats with gusto, \\
\hline 25 & dan yang gadang tanduknya, & And has a large horn, \\
\hline 26 & maka yaitulah jantannya." & Then that is the male bird, \\
\hline 27 & $\begin{array}{l}\text { Maka kembali daripada Datuak Suri Dirajo kepada } \\
\text { segala penghulu }\end{array}$ & $\begin{array}{l}\text { So all the leaders returned from meeting Datuk Suri } \\
\text { Dirajo }\end{array}$ \\
\hline 28 & dan orang besyar-besyar & as well as other dignitaries \\
\hline 29 & maka tiba di tengah medan. & arriving in the middle of the field, \\
\hline 30 & $\begin{array}{l}\text { Maka Cati Reno Sudah pun bertanya kepada Nakhoda } \\
\text { (Besar), }\end{array}$ & Cati Reno Sudah then asked the Great Captain \\
\hline 31 & "Apa kehendak Nakhoda Besar?” & "What is the intention of the Great Captain?" \\
\hline 32 & Maka sahut Nakhoda Besar, & The Great Captain replied, \\
\hline 33 & $\begin{array}{l}\text { "Adapun hamba (datang) kemari membawa unggas } \\
\text { dua ekor, }\end{array}$ & "Well the servants came here carrying two birds, \\
\hline 34 & manakah yang jantan, & Which one is the male. \\
\hline 35 & manakah yang betina, & Which one is female, \\
\hline 36 & kita bartakok-takok." & Let's play the puzzle," \\
\hline
\end{tabular}




\begin{tabular}{|c|c|c|}
\hline 37 & Maka ditakok oleh Cati Reno Sudah. & Cati Reno Sudah began to guess, \\
\hline 38 & Maka diberi makan keduanya di tengah medan. & He fed the two birds in the middle of the field \\
\hline 39 & Maka unggas itu edar- maedar makan, & Both birds circled the food, \\
\hline 40 & maka tantu tanda seekor, & A sign of the difference of a bird \\
\hline 41 & maka ditakok oleh Cati Reno Sudah. & Cati Reno Sudah has begun to guess \\
\hline 42 & "Maka yang kuat (makan) itulah yang jantan & The one who eats with more gusto is the male, \\
\hline 43 & Maka alah jua Nakhoda Besar, & Thus, the Great Captain lost, \\
\hline 44 & sekali-kali tiada & All was gone, \\
\hline 45 & dan malulah Nakhoda Besar, & and he was ashamed, \\
\hline 46 & sekali-kali tiada tamakan nasi dan sirih. & Never again to eat rice and betel nut., \\
\hline 47 & Ditarik unggas tadi, & Pulled away by these two birds \\
\hline 48 & $\begin{array}{l}\text { maka segala perahu ditinggalkan di tepi Bukit Batu } \\
\text { Patah. }\end{array}$ & $\begin{array}{l}\text { All of their boats were left on the edge of Bukit Batu } \\
\text { Patah, }\end{array}$ \\
\hline 49 & Maka berhenti di Bukit Batu Patah. & Then stopping at Bukit Batu Patah. \\
\hline 50 & Maka mufakat di sana isi perahu, & There was consensus there from the whole boat, \\
\hline 51 & serta Nakhoda. & And also the Captain, \\
\hline 52 & Maka sumpah sati di sana tatkala itu, & They swore a sacred oathin that place, \\
\hline 53 & "Janganlah kita ke Minangkabau jua, & "Never again will we come to Minangkabau, \\
\hline 54 & $\begin{array}{l}\text { segala raja-raja orang Pulau Perca lebih panjang bicara } \\
\text { daripada kita." }\end{array}$ & and all the kings of Perca Island to speak more of us " \\
\hline 55 & Sebab itulah tiada datang lai kepada kita. & Because of that, we should never come again. \\
\hline
\end{tabular}

The match was won again by the leader of the people of Tanjung Sungayang. At the end of the match, all the winnings belonged to the people of Tanjung Sungayang. The Great Captain's group left the area because they had lost the puzzle game. The "Teka-teki Unggas" episode consists of 55 units of analysis, as described in the Table 2.

The sixty-two units of analysis in the episode "Teka-Teki Kayu Tataran" and fifty-five units of analysis in the episode "Teka-teki Unggas" are then broken down into several lexia which transmit the meaning and plurality of meaning of the text. Lexia is built up by a collection of markers on narrative discourse into fragments. The fragment is formed from units of text that vary in length. Sometimes it can be in the form of words, sentences, phrases and even paragraphs. The separate parts of the fragment (lexia) become benchmarks for determining further functions. The follow-up analysis follows Barthes' five codes namely, the hermeneutic, semic, symbolic, proairetic and cultural codes.

\section{Discussion}

The process of finding meaning is done by re-arranging the discrete meanings that have been spread in a certain way. Thid arrangement is based on lexia that built the narrative in the two episodes of Tambo discussed. The "Teka-teki Kayu Tataran" episode consists of 22 lexias, while the episode "Teka-teki Unggas" consists of 17 lexias. This can be seen in Table 3 .

Tambo Minanagkabau as a literary text (historiography) is built by textual markers. The textual marker is then categorized as semiotic codes. Barthes used five codes in analyzing Sarrasine. This approach has been applied to the two episodes of Minangkabau Tambo discussed in this study. As a text, the two episodes of the Minangkabau Tambo contain textual markers in which there arelexias, which is then included in one or more of Barthes's five semiotic codes. Lexia are then classified across Barthes' five semiotic codes. Table 4 below describes the grouping of lexia into the hermeneutic code.

\section{Hermeneutic Code}

A hermeneutic code is the content of a textual marker that can raise questions that need to be answered. Lexia 1 in table 4 indicates a question about who are the boat people, where are they from, what are their goals for visiting the Minangkabau area, and so on. Leksia 2 adds to the focus oncuriosity contained in lexia 1 . Lexia 2 contains questions about the reason for bringing this type of wood, what is the wood for? It can even be followed 
Table 3. Lexia in the "Teka-teki Kayu Tataran" and "Teka-teki Unggas" Episodes

\begin{tabular}{|c|c|c|}
\hline \multirow{2}{*}{ No } & \multicolumn{2}{|c|}{ LEXIA } \\
\hline & "Teka-teki Kayu Tataran" & “Teka Teki Unggas” \\
\hline 1 & $\begin{array}{l}\text { The arrival of the group of people using a boat from } \\
\text { the sea. }\end{array}$ & Arrival of the Great Captain to the Island of Perca. \\
\hline 2 & $\begin{array}{l}\text { Bringing the sparrow dragon notched wood (kayu } \\
\text { tataran nago pipit). }\end{array}$ & Bringing a pair of fowl. \\
\hline 3 & Visiting the country of Limo Kaum. & Visiting Tanjung Sungayang. \\
\hline 4 & Reception by Suri Dirajo & Reception by the leaders and residents of the country. \\
\hline 5 & $\begin{array}{l}\text { The invitation to play puzzles by the Great Skipper to } \\
\text { Datuk Suri Dirajo. }\end{array}$ & Call for a puzzle game without betting. \\
\hline 6 & $\begin{array}{l}\text { The bet is choose correctly the heavier part of the } \\
\text { object. }\end{array}$ & Differentiating the sexes of both birds. \\
\hline 7 & The bet is for fifty kati of gold. & $\begin{array}{l}\text { All residents conduct deliberations to accept the } \\
\text { invitation. }\end{array}$ \\
\hline 8 & $\begin{array}{l}\text { All country residents agree to accept the invitation to } \\
\text { play the puzzle. }\end{array}$ & $\begin{array}{l}\text { Cati Reno Sudah askes for instructions to Datuk Suri } \\
\text { Dirajo. }\end{array}$ \\
\hline 9 & Everyone in the boat comesto watch the match. & $\begin{array}{l}\text { Datuk Suri Dirajo gives a strategem to solve the } \\
\text { puzzle. }\end{array}$ \\
\hline 10 & The puzzle match was held in Dusun Tuo. & $\begin{array}{l}\text { The puzzle match is carried out and witnessed by all } \\
\text { residents of the country. }\end{array}$ \\
\hline 11 & $\begin{array}{l}\text { Before the match Cati Reno Sudah asked the purpose } \\
\text { of the group's arrival to come to their country. }\end{array}$ & $\begin{array}{l}\text { Before the match began, Cati Reno Sudah had asked } \\
\text { the purpose of the arrival of the Great Captain to visit } \\
\text { their country. }\end{array}$ \\
\hline 12 & $\begin{array}{l}\text { The Great Captain argued that they were only visiting } \\
\text { the land of people who were clever and intelligent. }\end{array}$ & $\begin{array}{l}\text { The Great Captain replied that their arrival was to play } \\
\text { puzzles with people in the country using fowl. }\end{array}$ \\
\hline 13 & The puzzle match is carried out. & The match was won by Cati Reno Sudah \\
\hline 14 & $\begin{array}{l}\text { A notched wooden dragon sparrow is used as an item } \\
\text { to be guessed as to which is the top and bottom. }\end{array}$ & The Great Captain felt ashamed of his defeat. \\
\hline 15 & $\begin{array}{l}\text { Cati Reno Sudah weighs wood in the center of the } \\
\text { sparrow }\end{array}$ & $\begin{array}{l}\text { The Great Captain and his entourage left the land of } \\
\text { Tanjung Sungayang. }\end{array}$ \\
\hline 16 & $\begin{array}{l}\text { Cati Reno Sudah it has been supported by all residents } \\
\text { of the country who have succeeded in determining the } \\
\text { weights of the top and base of the wood. }\end{array}$ & $\begin{array}{l}\text { The group vowed never to come again to } \\
\text { Minangkabau. }\end{array}$ \\
\hline 17 & The match was won by Cati Reno Sudah. & $\begin{array}{l}\text { The reason for the oath was done because the people in } \\
\text { Minangkabau were very clever and intelligent.. }\end{array}$ \\
\hline 18 & $\begin{array}{l}\text { So all the gold in the boat and the gifts are given to the } \\
\text { inhabitants of the Dusun Tuo }\end{array}$ & \\
\hline 19 & The group fled and took a vow not to return. & \\
\hline 20 & $\begin{array}{l}\text { Their boat was left in the Sungai Emas and divided up } \\
\text { by residents. }\end{array}$ & \\
\hline 21 & They swear not to come back & \\
\hline 22 & People of Perca Island in his speech & \\
\hline
\end{tabular}


Table 4. Hermeneutic codes

\begin{tabular}{|c|l|l|c|}
\hline \multirow{2}{*}{ Lexia } & \multicolumn{2}{|c|}{ HERMENEUTIC } & \multirow{2}{*}{ Lexia } \\
\cline { 2 - 4 } & Teka-teki Kayu Tataran & Teka-teki Unggas & 1 \\
\hline 1 & Boating people & Then came the Great Captain to Perca Island. & 2 \\
\hline 2 & The notched wood & A pair of birds & 6 \\
\hline 6 & The contents of nature & Distinguish between the male and female birds. & 5 \\
\hline 14 & $\begin{array}{l}\text { Determine the end and base of the notched } \\
\text { wooden }\end{array}$ & No bets & \\
\hline 7 & Fifty kati bet & & \\
\hline 6 & Bet on nature & & \\
\hline 19 & So he ran away & & \\
\hline
\end{tabular}

by a question that intends to ask why bring this type of wooden artifact, why not other types of wooden artifacts. From questions arising in lexia 2, questions continue to emerge in lexia 6 , which states the type of bet. Lexia 6 raises even more intriguing questions. What is meant by "all of this world" ("isi alam")? What is the correlation betweenthis and the puzzle games. Even then a further question can also be raised, namely when did this puzzle game occur? One final question that is just as important is lexia 19, which contains the idea of an escape. Of course the reader's curiosity heightens when reading lexia 19 . Curiosity seems to reach a climax when correlated with lexia 19 compared to previous lexia, namely lexia 7 and 6 . Who came to bring fifty kati of gold to the Minangkabau country and then left the gold because they were forced to run after losing a puzzle (see table 4 on column "Tekateki Kayu Tataran")?

Parallel questions are also seen in the episode "Teka-teki Unggas". The opening question that must be uncovered is the answer contained in lexia 1. The lexia contains a big question regarding the identity of the Great Captain who returned to the land of the Minangkabau people. Who is the Great Captain? Lexia 2, in the episode "Teka-teki Unggas", raises further questions because it is stated in that lexia that they carry a pair of birds. What's the signficance of a pair of birds. Why did the Great Captain come to Perca with fowl? The question is still remains a focus through the content of messages contained in lexia 6, even lexia 5 in the "Teka-teki Unggas" episode. Through lexia 6, the curiosity of the reader is piqued to find answers about determining the sex of birds. What is the correlation of the sex of the poultry with the events of the past historical Minangkabau people?

This hermeneutic code must be linked to the situation that became the background of the creation of the second episode of the Minangkabau story. The process of linking this hermeneutic code to the historical, political, social and cultural situation that has occurred in the history of the Minangkabau tribal civilization, will be the material for the interpretation of the meaning of the next text.

\section{Semic Code}

Next, lexia are grouped into the semic code. Semic codes are codes contained in textual markers that contain connotative meanings. It appears that one lexia can be joined to one and or more semiotic codes. This can be observed in table 5 below. Leksia 19 in the episode "Teka-teki Kayu Tataran" simultaneously includes the hermeneutic code and semic code. Likewise, the case for lexia 5 in the episode "Teka-teki Unggas" can at the same time be included in the hermeneutic code and semic code. Consider the following table 5. Leksia 19 in the episode "Teka-teki Kayu Tataran" denotes the story of a group of people who were carrying out an oath. It then proceeds to lexia 21 in the same episode, which is to provide information stating that the group of people ran away after taking the oath. Even then such information is reinforced by lexia 22 which tells us that they were deterred from coming back because of the people on Perca Island in their speech.

Based on these three lexias $(19,21$, and 22), connotatively refers to an attitude of anger, hatred, even accompanied by a strong determination not to want to visit again the place (Perca Island) which has been a shame for a group of people coming from across the sea. The veiled meaning behind this semic code is the event of an angry group that came by boat to Perca Island. The outrage was caused by their deceitfulness due to the shrewdness and intelligence of the residents of the Island defeating them in playing puzzles. This is further analysed in the following table 5 . 
Table 5. Semic Code

\begin{tabular}{|c|c|c|c|}
\hline \multirow{2}{*}{ Lexia } & \multicolumn{2}{|c|}{ SEMIC } & \multirow{2}{*}{ Lexia } \\
\hline & Teka-teki Kayu Tataran & Teka Teki Unggas & \\
\hline 19 & So all the people swore there. & "What is the will of the Great Captain?" & 11 \\
\hline 21 & Never to go to Minangkabau and to Perca Island. & $\begin{array}{l}\text { "As for the servant (coming) come here with two } \\
\text { birds. }\end{array}$ & 12 \\
\hline 22 & The people of Perca are spoken to & $\begin{array}{l}\text { "As for the servant (coming) come here with two } \\
\text { birds." }\end{array}$ & 5 \\
\hline
\end{tabular}

Table 6. Symbolic codes

\begin{tabular}{|c|l|l|c|}
\hline \multirow{2}{*}{ Lexia } & \multicolumn{2}{|c|}{ SIMBOLIC } & \multirow{2}{*}{ Lexia } \\
\cline { 2 - 4 } & \multicolumn{1}{|c|}{ Teka-teki Kayu Tataran } & \multicolumn{1}{c|}{ Teka Teki Unggas } & \\
\hline 1 & A group of people who came by boat. & Then came the Great Captain to Perca Island. & 1 \\
\hline 5 & Puzzle game & Puzzle game & 10 \\
\hline 3 & The Great Captain & The Great Captain felt ashamed of his defeat. & 14 \\
\hline 20 & Then all the treasure was split by Laras Nan Dua & "Let us not go to the Minangkabau too" & 16 \\
\hline
\end{tabular}

There is a comparable situation which occurs in the episode "Teka-teki Unggas". Cati Reno Sudah, representing residents of the country playing puzzles, first needs to find out the purpose of the arrival of the Great Captain to visit his area. The lexia 11 in table 5 expresses the curiosity of Cati Reno Sudah. He felt the need to ascertain the intentions behind the arrival of the Great Captain to Perca Island, especially to Tanjung Sungayang. The Great Captain answers the question by saying that he and his entourage came with a pair of birds (lexia 12), then with these birds they invited the inhabitants of the land of Tanjung Sungayang to play puzzles without betting. The statement is contained in lexia 5. However, connotatively, the three lexias, namely lexias 11,12 , and 5 in the episode "Teka-teki Unggas" actually carry the seeds of conflict for the inhabitants of Tanjung Sungayang

(lexia 11), the negotiating capacity of the new arrivals with the indigenous populations (lexia 12), and the strategy of reconciliation of migrant groups to the Tanjung Sungayang population groups (lexia 5). The connotative meaning such as this will then reveal deeper layers of meaning and a more significant meaning at a later stage.

\section{Symbolic Codes}

Lexia is included in the symbolic code. Symbolic code is the content of textual markers that are symbolic of something that is in the realm of life, history and culture of people who need to find out. Historical, social and cultural knowledge is needed to be able to interpret it. The Table 6 explains more about the symbolic code.

Leksia 1 in the episode "Teka-teki Kayu Tataran" refers to the symbolic meaning associated with an historical event that occurred during the lights on Perca Island. "Perca" is the name of a location name used to refer to a place on the island of Sumatra, especially the Minangkabau area. The fleet came from another land to the Minangkabau area to expand its area. The fleet was from a large kingdom in Java, namely Majapahit. This event is recorded in historical records. This event became a dark shadow in the history of the Minangkabau civilization. The dark shadow that was about to be "divorced" through the presence of lexia 5 in the episode "Teka-teki Kayu Tataran". The connotative meaning contained in lexia 5 is a way to reconcile the dark shadow of expansion by the fleet that came from the sea. The puzzle game using a wood artifact is a strategy that relies on local wisdom, logic, and skills using words that are the basic capital of the Minangkabau people's character. This basic capital, possessed by the Minangkabau ethnic group, is processed and secreted through the Tambo narrative.

The end of the dark event is that all the inheritance in the Minangkabau land is divided into two, according to the applicable legal provisions in Laras Koto Piliang and Laras Bodi Caniago. Both of these sources of customary law differ in their pattern of logic and the way they are applied in the community. Laras Koto Piliang constructs a social and cultural system and legal logic 
Minangkabau society, arranged according to the principle of "from top to bottom" (top down), whereas it is the opposite in Laras Bodi Caniagio which uses a "bottom up" principle. The events embedded through lexias 1, 5, 3 and 20 in the episode "Teka-teki Kayu Tataran" shown in table 6 , connote how the original kinship structure in Minangkabau society, which was originally matrilineal, was then mixed with and coloured by a system that is patrilineal which came from outside the Minangkabau region. The indicator for this connotative meaning is based on lexia 1 namely, people who come by boat. This lexia 1 automatically maps the location and place of origin of the group. There are two coastlines that provide entrances for outsiders to come to the ancestral lands of the Minangkabau people, namely the west east coast of the island of Sumatra. When entering through the eastern coast line, it is most likely that it corresponds to the expansion of the Srivijaya kingdom into the Malay kingdom in $688 \mathrm{AD}$ as shown in Figure 1.

\section{Figure 1. Map of Sriwijaya Kingdom}

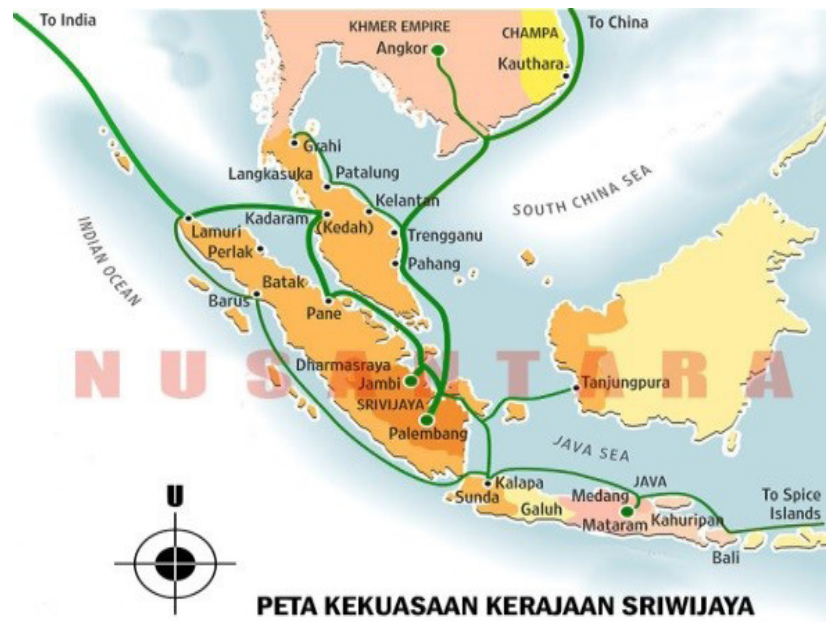

Source: Senadu (2015).
However, if the entrance is from the west coast of Sumatra, it is likely that this would have occurred during the expansion of the Samudera Pasai kingdom. This kingdom was founded by Meurah Silu in 1267 AD. The kingdom of Samudera Pasai is the first Islamic kingdom in Indonesia. Religion has patriarchal nuances, both Islamic civilisation as well as the civilisation brought by the Majapahit Kingdom, namely Hinduism. So lexia 1 in the second episode of Tambo as discussed, refers to that great power, namely the power of patriarchy.

The same idea is also contained in lexias 1, 10, 14, and 16 in the episode "Teka-teki Unggas" (see table 6, second column for symbolic codes). Lexia 1 connotes the arrival of the Great Captain to Perca Island. Implicitly, it can be understood that the arrival of the Great Captain is by ship or as part of a fleet that is large, and has helpers and bodyguards. The arrival is certainly not intended as just an ordinary visiteven though it it was stated by the group that they just wanted to play puzzles with the residents of the country they were visiting. Moreover, lexia 14 and 16 provides information that the Great Captain was very ashamed of his defeat in the puzzle game. As a result of the defeat, he and his entourage were forced to flee from Tanjung Sungayang .

In fact, there is a dark event which has occurred and is embedded in lexias 1, 10, 14, and 16 in "Teka-teki Unggas". Apparently, literature has folded the dark stories of the past into a simpler story, which is an ordinary puzzle game.

\section{Proairetic Code}

Proairetic code is the content of a textual marker that has the meaning of an action or treatment. This code is the main characteristic of the text that correlates with the logic of human action. Proairetic codes indicate activities that can be observed through actions. Table 7 describes the proairetic code found in "Teka-teki Kayu Tataran" and "Teka-teki Unggas".

Table 7. Proairetic Code

\begin{tabular}{|c|l|l|c|}
\hline \multirow{2}{*}{ Lexia } & \multicolumn{2}{|c|}{ PROAIRETIC } & \multirow{2}{*}{ Lexia } \\
\cline { 2 - 4 } & \multicolumn{1}{|c|}{ Teka-teki Kayu Tataran } & \multicolumn{1}{|c|}{ Teka Teki Unggas } & 5 \\
\hline 3 & The arrival of the Great Captain to Perca Island. & Come back to play puzzles. & 13 \\
\hline 5 & Invitations to play puzzles & Defeat the Great Captainfor the second time & \\
\hline 17 & $\begin{array}{l}\text { The defeat of the Great Captain who came from } \\
\text { the land opposite }\end{array}$ & & \\
\hline
\end{tabular}


Lexia's 3, and 5 in the episode "Teka-teki Kayu Tataran" as shown in table 7, illustrates actions that precipitate further acts. The act carried out by the Great Captain (lexia 3) had a bad impact on himself after taking the action described in lexia 5. The act of arrival (lexia 3) led to the puzzle game (lexia 5), which adversely affected the Great Helmsman that is, the occurrence of defeat (lexia 17). Similar acts also occur in "Teka-teki Unggas". The act of an invitation to play puzzles, as depicted in lexia 5 , finally also adversely affected the acts of the Great Captain (lexia 17). In fact, there are many more cultural codes contained in these two episodes of Minangkabau Tambo.

\section{Cultural Codes}

A cultural code is a code that is a reference for textual markers. This code is like a unversal marker for the text. This cultural code is found throughout the text. Through this cultural code, social and cultural phenomena can be understood or explained through text. Some examples are shown in table 8 below.

The five codes, exemplified by the lexia in each table, shows there are literary facts about the arrival of people (groups) who come to Perca Island (another name for the Minangkabau homeland) by boat. The group came from the sea (coast) and was led by a great captain. The two puzzles mention the presence of the Great . This literary fact indicates that the boat mentioned was not a small boat, but a large boat because it was stated that the boat was under the command of a Great Captain. The finding of literary facts such as this indicate ideas about social facts and Minangkabau history regarding the invasion of soldiers from the Majapahit kingdom in 1409 to the island of Sumatra.

Minangkabau society at that time was a vibrant empire called the kingdom of Pagaruyung. Majapahit's aims for invading Sumatra, included also wanting to conquer the kingdom of Pagaruyung, which was led by Adityawarman in 1347. However, the entourage of the Majapahit royal army reinforced by a fleet of hundreds of ships was said to have been defeated. The defeat occurred because the military entourage of the Majapahit kingdom was welcomed by the ninik mamak (traditional leaders in Minangkabau) who welcomed them in the land of Minangkabau. The friendly reception from the Minangkabau mamak is symbolised by the invitation to play puzzles. This invitation to play puzzles is offered because militarily, Pagaruyung's kingdom is far less powerful than the Majapahit kingdom. The king of the Pagaruyung kingdom is only a charismatic symbol, while those who are the actual leaders of the people arethe ninik mamak. Ninik mamak rule their people with the power of words used in their deliberations. Playing with words in negotiations is an essential skill that must be possessed by ninik mamak, especially those who are religious teachers. Proficiency in arguing and word play is a valuable inheritance for a prince and other mamak ninik. The puzzle game in the two case studies shown in the previous tables contains the idea ofskill in playing with words.

Table 9 reinforces the correlation between written markers contained in the two episodes of Minangkabau Tambo,the markers and the meaning and / or interpretation that is embedded in the relationship, that is, its signification.

In a semiotic analysis several markers are found in “Teka-teki Kayu Tataran" and "Teka-teki Unggas", such as the arrival of the group by boat, the Great Captain, the puzzle game, using bets and or not betting, the flight of the group from across the seaand vowing not to come to Perca again. These areclear references to the social facts and history of the Minangkabau at one time, especially those related to the story of the invasion of the Majapahit kingdom to conquer the Pagaruyung kingdom in

Table 8. Cultural Code

\begin{tabular}{|c|l|l|c|}
\hline \multirow{2}{*}{ Lexia } & \multicolumn{2}{|c|}{ CULTURAL } & \multirow{2}{*}{ Lexia } \\
\cline { 2 - 4 } & \multicolumn{1}{|c|}{ Teka-teki Kayu Tataran } & \multicolumn{1}{|c|}{ Teka Teki Unggas } \\
\hline 1 & People who come by boat from another land & $\begin{array}{l}\text { The arrival of the Great Captain for the second } \\
\text { time. }\end{array}$ & 1 \\
\hline 3 & Great Captain & Penghulu (head) & 4 \\
\hline 17 & $\begin{array}{l}\text { The event of the defeat of the Great Captain's } \\
\text { entourage }\end{array}$ & $\begin{array}{l}\text { The puzzle match is done in the middle of the } \\
\text { field }\end{array}$ & 10 \\
\hline 19 & The visiting group flees from the land & Defeat of the Great Captain for the second time & 13 \\
\hline & & Agree on all the contents of nature & 7 \\
\hline
\end{tabular}


Table 9. Correlations between markers in "Teka-teki Kayu Tataran" and "Teka-teki Unggas"

\begin{tabular}{|c|c|c|c|}
\hline \multirow[t]{8}{*}{ Teka-Teki Kayu Tataran } & Signifier & Signified & Signification \\
\hline & Boat people & $\begin{array}{l}\text { Invasion of forces from } \\
\text { outside }\end{array}$ & Historical tragedy \\
\hline & Notched wood artifact & puzzle game & Alibi \\
\hline & Has the contents of nature & $\begin{array}{l}\text { The right to rule over the } \\
\text { territory }\end{array}$ & Target \\
\hline & $\begin{array}{l}\text { Determine the tip and base } \\
\text { of the wooden artifact }\end{array}$ & Intuition and wisdom test & $\begin{array}{l}\text { Shrewdness and courage } \\
\text { test }\end{array}$ \\
\hline & Fifty kati betbets & Consequences in a match & $\begin{array}{l}\text { Betting on communal self- } \\
\text { esteem }\end{array}$ \\
\hline & Bet on nature & Surrender & Consequences of the match \\
\hline & So he ran away & Defeat & Confession and surrender \\
\hline \multirow[t]{4}{*}{ Teka-teki Unggas } & $\begin{array}{l}\text { The arrival of the Great } \\
\text { Helmsman for the second } \\
\text { time }\end{array}$ & $\begin{array}{l}\text { The second invasion from } \\
\text { outside forces }\end{array}$ & Repeated historical tragedy \\
\hline & A pair of birds & Balance & Balance \\
\hline & $\begin{array}{l}\text { Distinguish male and } \\
\text { female birds }\end{array}$ & Wisdom and thoroughness & $\begin{array}{l}\text { Shrewdness and test of } \\
\text { courage between the } \\
\text { Minangkabau and the army } \\
\text { of the Majapahit kingdom }\end{array}$ \\
\hline & No bets & Unconditional inducement & $\begin{array}{l}\text { Seduction as a last resort to } \\
\text { reach the goal }\end{array}$ \\
\hline
\end{tabular}

Minangkabau. The invasion was a sad story that had been experienced by the Minangkabau people. The episodes are historical stories for the subconcious memory of the Minangkabau people. At this stage, literature (in this case the puzzle) is used to heal a collective wound. Literature wraps up the idea of sad stories as a result of the invasion through the second puzzle story. Literature dissolves the collective sadness and hurt of the Minangkabau people. Local stories such as those contained in puzzles and folklore are actually important to be explored for a better understanding of the values contained in them.

Rosa (2017) states that in many local stories there is a message that is important for character education. However, socialisation of this type of story is rarely done. Of course it's not surprising if there are many people who don't know and understand the local story. They are more familiar with stories from abroad compared to stories belonging to their own people. Within this folklore can be found values to form a national character that is urgently needed today.

\section{CONCLUSION}

The "Teka-teki Kayu Tataran" and "Teka-teki Unggas" stories serve as a tool for disguising or masking a past tragedy that once existed in the history of the Minangkabau people. The tragedy relates to the invasion of the land of Minangakabau bya large kingdom on the island of Java . The invasion has left a dark, subconscious memory that does not want to be told clearly to subsequent generations. Literature has embedded the tragedy in symbolic and cultural codes and serves as a mediating tool between bitterness and honesty. Literature also reaches out to those who cannot be reached by ordinary logic. The study of these two episodes of Tambo Minangkabau, "Teka-teki Kayu Tataran" and "Teka-teki Unggas", demonstrates literature's complex mediating role in collective memories of tragic events.

\section{REFERENCES}

Andriani, T. 2012. "Pantun in Malay Life: Historical and Anthropological Approaches". Social Culture, vol 9, (2), pp. 195-212 - ejournal.uin-suska.ac.id

Barthes, Rolland. 1974. S / Z. English translation by Richard Miller. Britain: Brazil Blackwell, p. 19.

Batiran, Karno. B. Mansyur, M. Aan 2011. "Language Games in the Bugis Puzzles" Elong Maliung Bettuana “. 
Suar Betang Journal, - academia.edu.

Dick B, Metz C, Taylor M. 2010. "Film Language: A Semiotics of the Cinema". Books Abroad. Vol 49 (2), pp. 281. DOI: 10.2307 / 40129256. Published by JSTOR. De Linde Z. 2016. The Semiotics of Subtitling.

Djamaris, Edwar. 2002. "Introduction to People's Literature". Jakarta: Torch Foundation. pp. 34-37.

Eco, Umberto. 2018. "Semiotics and the Philosophy of Language". Reading Eco: An Anthology. Advances in Semiotics Series. Edited by Rocco Capozzi. “. Book Chapter, pp. 1-13. Bloomington: Indiana University Press.

Firmanto, Alfan. 2015. "Cirebon Islamic Historiography: Study of Cirebon Islamic Historical Manuscripts". Journal of Literature in Practice, Vol 13, (1), pp. 31-58.

Girsang, Romi C. 2016. "Masculinity in Television Advertising (Masculinity Semiotic Analysis in Television Ads Gudang Garam Merah Version" The Café “. FLOW, vol 2, (12). Accessed from https:// jurnal.usu.ac.id/ flow / article / view / 12738

Habsari, Sinung Utami Hasri. 2015. "Reading Barthes' Symbols". Journal of Research and Community Service III. Vol 2 (3), pp159-168.

Isaac, M. Taufik. and Moh. Mochsen sir. 2005. "Reading of Roland Barthes's Semiotic Code of Architectural Buildings at Every Cathedral in France by Mario Botta". Hue: Journal of Architecture. Vol 2 (1), pp. 85-92.

Jensen, Klaus B. 2015. Semiotics. International Encyclopedia of the Social \& Behavioral Sciences (Second Edition). Book Chapter, pp 592-597. Elsevier. Accessed fromhttps: //doi.org/10.1016/B978-0-08097086-8.95033-5.

Krebs, Katja. 2018. "Historiography”. Book Chapter in The Routledge to Companion to Adaptation. pp. 55-57. London: Routledge.

Koswara (undated). "Semiotic interpretation of Wawacan Prabu Kean Santang Aji".

Accessed from http://file.upi.edu/Dirsite/FPBS/JUR. PEND._STORY_DAERAH/195906141986011DEDI_KOSWARĀ/INTREPRETASI_SEMIOTIK TERHADAP_WAWACAN.pdf.

Lustyantie, Ninuk. (2012). "Semiotic Approach to Roland Barthes's Model in the Work of French Literature". State University of Jakarta. Accessed from http:// pps.unj.ac.id/publikasi/dosen/ninuk.lustyantie/16.pdf

Lutzeler, Paul. M. 2015. "History and Literature" . International Encyclopedia of the Social \& Behavioral Sciences (Second Edition). pp. 97-101.

Nuswantara, Jaka Priyo. 2014. "Social Messages in Journalistic Photos (Semiotic Analysis in Books“ Jakarta Banal Aesthetics, Chapters I, III, V, and
VII) “The Messenger Journal: Vol 6, (1), pp. 1421. DOI:Accessed from http://dx.doi.org/10.26623/ themessenger.v6i1.163.

Pramudia, Christian A. 2012. "Meaning of Gie Character's Intellectual Resistance in Screenplay Scripts". Journal of Communication Sciences, 2012. Accessed from http://eprints.upnjatim.ac.id/3184/1/5.

Son, I Nyoman Darma. 2011. "Is It Possible to Think of the End of the 20th Century Balinese Literature Entering a Golden Era?" Journal of Bali Studies, vol 1, (2), pp. $159-185$.

Rosa, Silvia. 2017.: "Transformation Form Of Folktale To Be Creative Writing As Capital Formation Of National Character". Accessed from http://repo. unand.ac.id/cgi/users/home?screen=EPrint $\% 3 \mathrm{~A} \% 3$ AView\&eprintid=5341

Senadu (2015). “Sriwijaya Kingdom's Expansion and Diplomacy". Accessed from https://4. bp.blogspot.com/-ZGaRuGECb4I/Vjav499vjYI/ AAAAAAAAcsk/ceWyFgK-C2c/s640/PETAKEKUASAAN-KERAJAAN-SRIWIJAYA.jpg.

Siahaan, Evan. 2015. "Understanding Pentecostalism through the Frame of Luke's Historiography in Acts". Enthusiastic Journal: Journal of Theology and Service. Vol. 4, (7), pp. 60-81.

Gayatri, Spivak. 2012. "Subaltern Studies: Deconstructing Historiography". Book Chapter. Other Worlds: Essays in Cultural Politics. London: Routledge. pp. 197-211.

Widyatwati, Ken. 2015. "Faruk Short Story" City Bus "In Roland Barthes's Semiotics.”. HUMANIKA Vol. 22, (2), pp 58-65.

Wijana, I Dewa Putu. 2013. "Language Pride As Reflected in Puzzle Discourse". International Seminar Proceedings. Language Maintenance and Shift 3. 2-3 July, 2013, pp. 26-30. Master's Program in Linguistics, Diponegoro University collaboration with Central Java Province Balai Bahasa.

Wong, May L-Y. 2018. “Analyzing Visual Imagery: Semiotic Connecting and Cognitive Perspectives". BRILL. Volume 4: Issue 1 DOI: Accessed fromhttps://doi. org/10.1163/23526416-00401006.

Zlatev, Jordan. 2015. Cognitive Semiotics. International Handbook of Semiotics. Vol 1. Book Chapter, pp. 1043-1067. 